\title{
Khvylovism: Sources of the Worldview Guiding Lines
}

\author{
L. Turchina \\ Zaporizhzhya National Technical University \\ lturchina@ukr.net \\ orcid.org/0000-0001-5550-1943
}

Key words: khvyliovism, outlook, nationalism, bolshevism.
The article looks into the birth and formation of the ideology of so called Khvyliovism. It is true that childhood and youth of M. Khvyliovy are considered and analyzed in the article. His name is embodied in this ideology. Two autobiographies and memoirs of friends are used as the main sources. The article presents the circumstances of the birth of the future writer, clarifies the nature of family ties previously unknown to the wide scientific community. It is determined that M. Khvylovy began to write in Ukrainian language. His further attempts to combine in his outlook two incompatible trends, «bolshevism» and «nationalism», led to a symbolic act - a trap during the First World War at a soldier rally of two bows on a coat of arms - red and yellow-blue.

\section{Хвильовізм: витоки світоглядних орієнтирів}

\author{
Л. Турчина \\ Запорізький національний політехнічний університет
}

Ключові слова: хвильовізм, світогляд, націоналізм, большевизм.
Стаття висвітлює питання, пов'язані із зародженням та формуванням ідеології хвильовізму. Справедливо, що розглядаються та аналізуються дитячі й юнацькі роки саме Миколи Хвильового, оскільки з його прізвищем уособлюється ця ідеологія. У якості основних джерел використовуються дві автобіографії та спомини знайомих. У статті наводяться раніше мало відомі широкому науковому загалу обставини народження майбутнього письменника, з'ясовується характер родинних зв'язків, визначено, що починав писати М. Хвильовий саме українською мовою. Подальші його намагання поєднати у своєму світогляді дві несумісні течії «большевизм» та «націоналізм» призвели до символічного акту - причеплення під час I Світової на солдатському мітингу двох бантів на шинелі - червоного та жовто-блакитного.
The life of such a person as Mykola Khvylovyi will remain a very topical problem at least until the end of occupation of Ukrainian territories by the Russian army. The slogan which now sounds like "Get Away From Moscow!" actually arose in the middle of the 1920 s as a result of the situation in Ukraine at the time. A literary discussion on the quality of literary works begun on the pages of the weekly supplement "Culture and Life" in April 1925 a year later turned into a political one after the famous letter of Stalin to Comrade L. Kaghanovich [1].

We can say that the events of the mid-1920s contributed to the rise of Ukrainian culture in general, after having received the loud name "Shot down Renaissance". And the key person in this process was Mykola Khvylovyi. An official Communist Party press invented even the name of the literary flow impersonated by the bearer of the name - khvylovism.
Consequently, khvylovism in the broad sense is the socio-political trend of the 1920s of the patriotic direction of the left. It is based on the firm conviction that building an independent Ukrainian state with a socialist system is possible.

The purpose of this article is to study and analyze the process of forming a creative personality, to find out the factors that influenced the formation of the worldview of the head of khvylovism, in fact, of Mykola Khvylovyi himself.

Chronological boundaries of the article cover the period from 1893 to 1919.

Issues connected with the formation of the artist's personality attract considerable attention. Unfortunately, specifically this time of life and activity of M. Khvylovyi is the least known. Sources of this period can be divided into two groups. The first ones are autobiographical. We have a short biography of a member of the Ukrainian Bolshevik Com- 
munist Party (April 1919, party ticket №280655) Nikolai Grigorievich Fitilov (literary pseudonym Mykola Khvylovyi) "dated 20.11.1924 [2, p.830-837], which was written on request of party bodies. The language of the document is laconic, official. A small "Excerpt from autobiography" [3, p.106-108] presents a real picture of M. Khvylovyi's life in childhood. But he has no equal in understanding the worldview of a child teen - young adult M. Khvylovyi. The second group of sources is the memories of the closest surrounding.

Thus, Mykola Khvylovyi was born on the 1 December in an old style (14 December in new) in 1893 in the village Trostyanets of the Okhtirsky district of the Kharkiv province into the family of the teacher Grygoriy Oleksiyovich Fitilov who, according to 0 . Ghan, came from the impoverished noble family [4, p.9]. It is known that his mother Elizaveta Ivanovna (maiden name - Tarasenko) was the daughter of the accountant of the estate of a millionaire-sugar producer L. Kenig. As Yu. Lavrinenko points out: “...his grandfather was a Frenchman, and his grandmother was a Ukrainian serf" $[5$, p.399]. At the time of Mykola's birth she was married to G. Fitilov. The vast majority of contemporaries and researchers of the writer's life believe G. Fitilov to be M. Khvylovyi's father. At least, M. Khvylovyi himself wrote about $G$. Fitilov as his own father [2, p.830; 3, p.106].

However, P. Vasylyevskyi, basing on memories of Alexander Kiselov, a distant relative of M. Khvylovyi for maternal line, A. Svashenko, a resident of the house "Word" and the famous writer-prisoner V. Gzhytskyi claims that M. Khvylovyi's father was a wealthy peasant from the former Cossacks from the Okhtirka Dmitro Dorosh [6]. He believes that the mother of a future writer at a certain time "sinned" with D. Dorosh. The author of the article is confident that Khvylovyi knew the secret of his birth and his father's identity since his youth. However, communicating constantly with D. Dorosh, writer did not disclose the secret, looking after his mother's honor and avoiding compromising his reputation because of "kurkulstvo" (being too rich in the eyes of the authorities) of D. Dorosh. An indirect confirmation of the version of P. Vasilevskyi is A. Kobets's evidence that tells the stories that were rumored in the early 1920s in Kyiv about illegitimate M. Khvylovyi [7, p.107]. And it was also mentioned about a "medium" Dorosh by V. Vynnychenko in his notes on the suicide of M. Khvylovyi [8, p.207]. In support of his version, P. Vasilevskiy gives an ironic-humorous stanza, which belonged to M. Khvylovyi and was written in the early 1920s

"I am not a candlewick*, 'cause between us - wall of brick.

And my mom is not like that

So am I Cossack's offset..."[6].

* - candlewick is in Ukrainian "fitil"

Similar biographical facts are unlikely to be documented elsewhere. And, if we assume the legitimacy of the version of P. Vasilevskyi, it is still necessary to take into account that M. Khvylovyi's childhood was spent next to G. Fitilov and for some time he considered him to be his father.

G. Fitilov came to teach to Trostyanets in the late 1880s. It was a man of peculiar demands and habits that had a desire to instill in Mykola the love for populism. To a certain extent he succeeded: according to M. Khvylovyi's own statement, "I still cannot make away with the populist odor" [9, p.840]. The writer believed that $\mathrm{G}$. Fitilov paid little attention to children, who were five in the family - two sons and three daughters, because none of them received the traditionally necessary education, taking into account the social status of his father [6].

What is interesting is the fact that the future Ukrainian writer was brought up in Russified family. Who instilled in the child a love for Ukraine and its language? It turns out that it was a grandmother who spoke Ukrainian and in dark Slybozhansk evenings she told little Mykola fairy tales about brownies, wood spirits etc. From Grandmother the future writer learned to speak Ukrainian [9, p.840]. Thus, Tarasenko family was the basis upon which M. Khvylovyi's Ukrainian national consciousness began to emerge.

From the autobiographical source we discover that family life of little Mykola was not happy. There was little peace between G. Fitilov and his wife. Moreover, Mykola, who was the eldest in a family among children, was the only defender of his mother, when his father often came home drunk far into the night and began to pull mother's hair [3, p.106].

"Obviously, precisely in these years life began to educate me as an atheist," wrote M. Khvylovyi. The fact is that he asked God to protect his mother from the violence of $\mathrm{G}$. Fitilov:

“- God, - silently I pray, - where do you look?

But it was a desert around me and I did not hear any answer "[3, p.106].

Obviously, the family life of the Fitilovs' went wrong, in 1904 they divorced. P. Vasilevskiy says that the birth of Mykola led to a breakup [6], despite the fact that besides Mykola, G. Fitilov with his wife had four more children together.

Elizaveta Ivanivna moved with her children to the farm Zubivka to the estate of his native sister 
married to the landlord M. Smakovskyi where she stayed for about two years. Later she found a job at the parochial school of the village of Chernechchina in Bogodukhovsk and then in a folk school in the village of Demyanovka, not far from Dikanka. According to L. Smakovskyi, Mykola remained with the Smakovskyis to continue his education after his mother had moved. He graduated from the Kolontayiv Elementary School, where he was probably brought along with a cousin. After the graduation he was given to the high school of the town of Krasny Kut. Kolontaevskaya Elementary School and Krasnokutsk Higher Elementary School were the only educational institutions graduated by $M$. Khvylovyi [4, p.11].

A big role in the formation of the national worldview of Khvylovyi was played by the teacher of the Russian language and literature of Krasnokutsk High School A. Krivochatskyi. As a conscious Ukrainian in his lessons in the history of Russian literature he did not overcome any case to show his students the oppression that Russia caused Ukraine through persecution of Ukrainian culture. In addition, the sympathies to Ukraine in the soul of the young Ukrainian were supported by "Ukrainophile", the teacher of Kolontai school 0. Selivanovskyi and his wife $[4, \mathrm{p} .20]$.

The future writer did not get a solid education. All further attempts to give him high school education did not succeed. The first unsuccessful attempt to obtain a certificate was connected with 0khtyr gymnasium. Okhtyr men's progymnasium was formed at the end of the XIX century and in 1900 it was transformed into a gymnasium. According to the memories of the Ukrainian poet P. Grabovskyi, the Okhtyr educational institutions "represented in most cases by raw dirty half-fallen huts or huddled under one roof with rebels and taverns, they were very badly heated, had never been repaired, left unattended and more served as sources of all kinds of infectious diseases, than the nurseries of the national education ... “[10, p.431].

Mentioning of Okhtyr gymnasium in "Brief Biography" is explained by the fact that M. Khvylovyi brings to the attention of the party triad his "childish revolutionary". He claims that his studies at the gymnasium were terminated due to his participation in the Ukrainian revolutionary society. G. Fitilov was recommedned to take his son to the apartment of the local gendarme [2, p.830]. 0. Ghan gives a more detailed picture of the "revolutionary activity". According to him, M. Khvylovyi, somewhere got outlawed literature, conducted political propaganda among the dowry peasants and hired labor, maintained a connection with a student-revolutionist from the neighboring Konstantinovsk sugar-refinery [4, p.15].

After M. Khvylovyi entered Bogodukhiv gymnasium, where M. Smakovskyi sent him, he did not succeed there either. When M. Khvylovyi lived in Bogodukhiv he had some friends who were socialists-revolutionaries. The director and inspector of the provincial high school had some troubles with the Bogodukhiv police. The influence of M. Smakovskyi in local power circles was enough to save his nephew from the great scandal for some time. However, since the young man did not calm down and, in addition, despised the directorate it could not last for long. The management of the educational institution advised M. Smakovskyi to take the nephew from the gymnasium and keep him under his supervision [4, p.15].

0 . Ghan does not submit any convincing documents concerning these facts. But this course of events is logical and corresponds to the circumstances of that time. It was in 1910-1914 that the revolutionary struggle against the Russian autocracy became more active, encompassing not only student but also high school circles. Ukrainian political parties raised again on the agenda the issue of introducing the Ukrainian language and literature as separate subjects into the educational process.

M. Khvylovyi 's audacity to the leadership of the gymnasium was also not an abstract rebellion of the dissatisfied young man. L. Smakovska testifies that even before the gymnasium Mykola read a lot of poetry of T. Shevchenko and other Ukrainian poets and he recited them by heart using good Ukrainian language [11, p.15]. According to this, there are reasons to believe that $M$. Khvylovyi came to the gymnasium with well-formed national sympathies. In gymnasia at that time the official Russification and strict discipline prevailed. Naturally, the freedom-loving, proud character of the young man with different manifestations of national consciousness could not avoid rebelling. And this, in fact, could be the main reason for his expulsion from the gymnasium.

Failure with learning forced the boy to look for a job to earn money for bread. According to 0. Ghan, M. Khvylovyi at this time was employed as a correspondent in the office of $M$. Smakovskyi and in 1914-1915 he worked as a locksmith at the Krasnokutsk craft school, but did not stay for a long time [4, p.12].

As for the writer's life during the next few years, it is difficult to trace them chronologically. The sources that indicate that period and the research 
of scientists are controversial. Autobiographical documents describe the events of his "travel" around Ukraine interrupted by war, service in the royal army, participation in revolutionary events and civil war. In order to determine the ideological basis of certaim acts of $M$. Khvylovyi sometimes they even describe unlikely facts $[2, p .830-840 ; 3$, p.106-108]. Unlike the writer who almost does not connect the years with Bogodyukhiv and Rublivka, his contemporaries testify that he did spend most of this time in his native places [12].

Obviously, it is more reasonable to trust rather the memories of the aforementioned authors than the writer himself, because they were written in a "free society" and they aimed at correcting the distortions of M. Khvylovyi 's biography. The writer could mercenarily conceal issues related to everyday work to show instead "heroic" episodes, deliberately distorting the facts.

So, as M. Khvylovyi wrote, on the eve of the war he worked as a laborer, a loader etc.; conducted propaganda work among the workers. The writer points out that this situation lasted almost until the declaration of the war [2, p.831]. It is interesting, in our opinion, that the fact that even M. Khvylovyi himself differently describes the same course of events. If the official biography refers to the ideological principles of propaganda work [2, p.831], then "Excerpt from autobiography" contains memories about the difficult financial situation of the young hungry "traveler" [3, p.107].

Reading the first lines of sources on this period, one understands that a village boy first thinks about his ideological baggage inherited from the populist G. Fitilov. He notices proletariat, becomes its member to continue the propaganda work, but unexpectedly gets lost in the "flow of thousands of workers" [2, p.831]. Not used to this attitude, M. Khvylovyi leaves his job at the Druzhkivk factory. Then he goes to Taganrog, where he works as loader, then vendor of carbonite, but "I did not stay at any of these places for a long time, because I could not tolerate spread of labor exploitation, secondly, I felt lonely and I craved after stiff's liberty", says the writer. M. Khvylovyi connects the ideological essence of this period of his life with intuitive anarchism. He admitted that little did he know about the principles of anarchism only after one brochure of M. Bakunin [2, p.831].

The lines from "The excerpt from autobiography" contradict such an official characteristics of this period. The author admits that he blesses these years of his life so they were safely happy. "Only one dark spot is in them, and it is starvation" [3, p.107].
For three days he did not eat anything, because he ran out of money and he could not find any work. A hungry boy decided to ask for bread in the house of a wealthy Cossack:

"Aunty, give a piece of bread", I timidly asked.

"Many of you walk here," she said, and closed the window. I felt my ears burning and not because she had begrudged a piece of bread, but because I betrayed myself "[3, p.107].

Later some biographers, having learned about the circumstances of this period of the writer's life, omitted his social origin from the working masses. Instead, the party leaders accused M. Khvylovyi and his surrounding that they "to intentionally increase the authority of Khvylovyi hoaxed his working origin" [13, ark.4]. Obviously, this situation arose because writer's biographers were underinformed and the author himself did not participate in it. The writer was always embarrassed when he was called a worker, because he believed that people might think that owing to this he was trying to gain a "rank". "From these years, wrote M. Khvylovyi, what "factory" things I had were a proletarian (not illustrative) physiognomy, financial situation and spirit of protest" [9, p.840-841]. With such life experience and ideological principles M. Khvylovyi met the World War I.

The events of the World War I drastically changed the ideological views of M. Khvylovyi. Unfortunate$l y$, the information about this period is controversial. The disagreements begin with the question of M. Khvylovyi's time of recruitment to the current army. As he writes this happened in early 1915 [2, p.841], the date indicated in the biography of the writer and 0. Ghan [4, p.17]. However, according to P. Shyhymaha, he met Mykola in the autumn of 1915 when he was living with his mother in the village of Demyanivka. In the winter of 1915-1916 the future writer took an active part in the drama circle in the neighboring Rublivka and at that time he showed a "deep national consciousness" [14, p.113-114].

P. Shyhymaha does not mention what M. Khvylovyi was doing in 1916. However, as we know from the testimony of M. Khvylovyj [9, p.840] confirmed by L. Smakovskaya [4, p.16] being expelled from the gymnasium he did not give up science. In addition to the general reading of artistic works, Mykola learnt French and studied high school textbooks. There are reasons to think that he wanted to get a certificate externally. In those days this way of acquiring secondary education for poor children was very widespread. In such a way future close friends and supporters of M. Khvylovyi: M. Kulish, I. Dneprovskyi, 0. Dosvitnyi graduated from the high school. 
In the spring of 1916 this question was actual to M. Khvylovyi, because at that time the law was abolished that the eldest son of parents having many children was not to be mobilized. So M. Khvylovyi had to go to the army and secondary education would give him certain privileges. We do not know if an attempt to pass exams was unsuccessful or something else prevented the young man from taking this step, but he did not receive a certificate $[9$, p.840]. By the way, we have to emphasize the writer's retentive memory. Having read the piece once, he remembered it so well that he could quote it later!

P. Shyhymaha mentions the first works of M. Khvylovyi. He claims that M. Khvylovyi read them to him in July 1916 in Bogoduhov where he had moved in the spring of that year. They were written in prose in Ukrainian in the form of travel notes [14, p.113114]. By the way, this fact refutes the generally accepted view that M. Khvylovyi started as a poet [15, p.14]. According to 0. Ghan's chronology, the reading of works took place before 1915; however, the author does not indicate their form. M. Khvylovyi, receiving favorable reviews from fellow critics, sent his manuscripts to editors of some magazines. None of these attempts succeeded, but apparently this did not prevent M. Khvylovyi from continuing his writing [2].

P. Shyhymaha does not agree with the opinion expressed by $\mathrm{G}$. Kostyuk in the introductory word to the five-volume publication of the works of $M$. Khvylovyi that M. Khvylovyi volunteered to go to the army in the spring of 1915 . He points to the autumn of 1916, describing in detail the fact that “Mykola went to the army from my house. Malyk and I saw him off [...], my mother gave him food to take along" [14, p.115].

Thus, it becomes apparent that P. Shyhymaha's description of M. Khvylovyi's biography is more specific and consistent. Why did the writer himself not mention the above facts? Perhaps in order to exaggerate "revolutionary" and "rebelliousness", leaving in the shadows the events of everyday life. If we follow the statement of P. Shyhymaha, M. Khvylovyi was mobilized to the army in the autumn of 1916 and he went there voluntarily (all authors agree with this fact). However, further M. Khvylovyi states that he fell into the Vaschenkivsk barracks of Kharkiv [2, p.832] and P. Shyhymaha claims that at the end of 1916 M. Khvylovyi was "still in the training in Chuguev and sent us letters from there" [14, p.115]. This fact is confirmed by 0 . Ghan, who writes that M. Khvylovyi got into the 7-th troop of the thirtieth reserve regiment in Chuguev [4, p.17].
What we know about the front-line period of $M$. Khvylovyi's life is just that that at first he was a private infantryman of the 325th Tsarevskyi regiment, occupying positions in the Volyn bogs. "Fights, marches, lice, infantry strap" - he could endure all this physically, but for his moral state this time became a terrible crisis- "a period of complete spiritual decline." After it turned out that he was well acquainted with chemistry he was transferred to the ninth chemical team [2, p.832]. It is likely that M. Khvylovyi did not have time to participate in significant military events, because in the winter of 1916-1917 there was already a positional war. However, he watched and took an active part in the soldiers' revolutionary movement. M. Khvylovyi witnessed the time when a mass of millions of soldiers was in a state of uncertainty and chaos. Departed from his Ukrainian environment he quickly fell under the influence of the Petersburg bolshevik worker, who campaigned against the war. According to the writer, it was the front that made him bolshevik [3, p.107].

At the beginning of 1917, the writer was in Romania. By that time he had already gained popularity among the soldiers "owing to revolutionary propaganda for the war against own rear area and for the end of the war against the Germans and other enemies like the Galician or Bukovynian" [3, p.107]. Petersburg's worker in the person of M. Khvylovyi received a capable student: he was elected a member of the regimental council of the soldiers' deputies and shortly thereafter as a deputy to the Army Congress of the 9th Army of General P. Lechitsk, where he first met Ukrainian Army Council (Roman, Romania) [2, p.832].

Getting acquainted with the views of the members of the Ukrainian Army Council on the war, political situation, etc., in our opinion, revealed the weakness and shallowness of the Bolshevik ideas of M. Khvylovyi. A national political idea, that was new for him, influenced him a lot. It turned out that at the congress $M$. Khvylovyi pinched to the chest two bows: red and ... yellow and blue [3, p.107].

Thus, we can assert that due to the better organization of the Bolshevik ideology, M. Khvylovyi initially fell under its influence, but acquaintance with the weakly organized national idea radically overturned his conception. These two bows, where red was first because of the current requirements, are precisely an example of this controversy. At this stage of the revolutionary events, the young man was intoxicated with Bolshevik propaganda. They spoke about the right of nations of self-determination and a temporary alliance between the Bol- 
sheviks and the Ukrainian parties that sought autonomy of Ukraine. In addition, without realizing the principle of democratic centralism, M. Khvylovyi then understood bolshevism as the decentralized power of the Soviets [2, p.832]. So, having a vague idea what was closer to him, the writer did not make a final decision which of the political camps to join. Considering himself a Ukrainian Bolshevik, he tried to unite in his worldview two incompatible ideological positions: the Bolshevik communist idea and the Ukrainian national spirit. [3, p.107].

Thus M. Khvylovyi belonged to those sections of the population who before the revolutionary events of 1917 clearly showed their Ukrainian sympathies. The events of 1917-1919 - the uncertainty of the Ukrainian parties regarding their political program, their inability to govern the mass national movement, as well as the active Bolshevik propaganda supported by organized military groups - led M. Khvylovyi like many other conscious Ukrainians to the Ukrainian Bolshevik Communist Party. This happened in early 1919, apparently, during the capture of the M. Khvylovyi's hometowns by Bolsheviks. The formal affiliation of M. Khvylovyi to the Ukrainian Communist Party did not become an obstacle to the artificial combination in his worldview of the Bolshevik and national ideologies. Regarding the facts that M. Khvylovyi puts in his autobiographical works and which contradict the witnesses of the events, it seems that he deliberately allows those inaccuarcies in order to express his adherence to the current regime and the ruling party. Probably, the time of writing (1924) was the period in the life of the writer when he was not yet about to "go against the current," but tried to arrange his life in an orderly way. So we cannot fully trust the indicated documents.

It should also be added that the writer's period of life from birth to World War I is the least studied and examined. Unfortunately, it does not seem possible to study in more detail the events of the war today, and therefore the mentioned problem requires further research.

\section{Source and Literature}

1. Панченко В. Історія гасла «Геть від Москви!» // День (Київ). - 2019. - №3 4. [Електронний ресурс]. Режим доступу: URL: http://www.day.kyiv.ua/uk/article/ukrayinci-chytayte/mykola-hvylovyy-istoriya-gasla-get-vid-moskvy?fbcl id=IwAR0tWPgr4aRdqAq7LCoK1mY3bNPMbIZqGnCbMXKnABVS8MZI-7iilnHOzvA (20.03.2019).

2. Хвильовий М. Краткая биография // Хвильовий М. Твори: У 2 т. К: Дніпро, 1990. Т.2. С.830-837.

3. Хвильовий М. Уривок з автобіографії // Вітчизна (Київ).1987. №12. С.106-108.

4. Ган 0. Трагедія Миколи Хвильового. (Б/м.): Прометей, (б/д.). 77 с.

5. Лавріненко Ю. М. Хвильовий. Літературна сильвета // Лавріненко Ю. Розстріляне відродження. Антологія. 1917-1933. Поезія - проза - драма - есей. Мюнхен, 1959. С.393-405.

6. Василевський П. Агонія Миколи Хвильового під тінню голоду і смерті // Буковинське віче (Чернівці). 1993. 8 грудня.

7. Кобець О. Микола Хвильовий // Хвильовий М. Твори: У 5 т. Нью-Йорк - Балтимор - Торонто: 0б'єднання Українських Письменників «Слово» і Українське Видавництво «Смолоскип» ім. В. Симоненка, 1986. Т.5. С.153-167.

8. Винниченко В. Із щоденних нотаток про самогубство М. Хвильового і М. Скрипника // Хвильовий М. Твори: У 5 т. Нью-Йорк - Балтимор - Торонто: 0б'єднання Українських Письменників «Слово» і Українське Видавництво «Смолоскип» ім. В. Симоненка, 1986. Т.5. С.215-227.

9. Хвильовий М. Листи до Миколи Зерова // Хвильовий М. Твори: У 2 т. К: Дніпро, 1990. Т.2. С.840-881.

10. Історія міст і сіл УРСР. Сумська обл. К., 1973. 694 с.

11. Костюк Г. До нового трактування біографії М. Хвильового // Хвильовий М. Твори: У 5 т. Нью-Йорк - Балтимор - Торонто: 0б'єднання Українських Письменників «Слово» і Українське Видавництво «Смолоскип» ім. В. Симоненка, 1986. T.5. С.15-36.

12. Гащенко Д. Листи до Г. Костюка // Хвильовий М. Твори: У 5 т. Нью-Йорк - Балтимор - Торонто: Об'єднання Українських Письменників «Слово» і Українське Видавництво «Смолоскип» ім. В. Симоненка, 1986. Т.5. С.39-51; Шигимага П.І. Факти до біографії М. Хвильового // Хвильовий М. Твори: У 5 т. Нью-Йорк - Балтимор - Торонто: 0б'єднання Українських Письменників «Слово» і Українське Видавництво «Смолоскип» ім. В. Симоненка, 1986. Т.5. С.113-117; Коваленко В.Я. Богодухівщина в часи Хвильового // Хвильовий М. Твори: У 5 т. Нью-Йорк - Балтимор - Торонто: 0б'єднання Українських Письменників «Слово» і Українське Видавництво «Смолоскип» ім. В. Симоненка, 1986. Т.5. С.118-123.

13. * Інформаційний огляд Д. Галушка «Про окремі факти проявів націоналізму в літературі, критиці, театрі, музиці, образотворчому мистецтві та в літературних працях М. Скрипника». - Центральний державний архів громадських об'єднань України (ЦДАГО України). Ф.1. 0п.20. Спр.6220. Арк.4.

14. Шигимага П.І. Факти до біографії М. Хвильового. // Хвильовий М. Твори: У 5 т. Нью-Йорк - Балтимор - Торонто: 0б'єднання Українських Письменників «Слово» і Українське Видавництво «Смолоскип» ім. В. Симоненка, 1986. Т.5. C.113-117.

15. Жулинський М. Талант, що прагнув до зір // Літературна Україна (Київ). 1989. 27 серпня. С.14. 